\title{
Effects of zinc and manganese as foliar spray on pomegranate yield, fruit quality and leaf minerals
}

\author{
M. Hasani ${ }^{1}$, Z. Zamani ${ }^{*}$, G. Savaghebi ${ }^{3}$, R. Fatahi ${ }^{2}$ \\ ${ }^{1}$ M.Sc. Student, Department of Horticulture Science, University of Tehran, Karaj, 31587-77871, Iran. ${ }^{2}$ Professor \\ and Associate Professor, Department of Horticulture Science, University of Tehran, Karaj, 31587-77871, Iran. \\ ${ }^{3}$ Professor, Department of Soil Science, University of Tehran, Karaj, 31587-77871, Iran. *Corresponding \\ Author:zzamani@ut.ac.ir
}

\begin{abstract}
Effects of foliar sprays of zinc and manganese sulfates on the fruit yield and quality as well as leaf nutrients concentration of pomegranate were studied during 2010 growing season in an orchard with a soil $\mathrm{pH}$ of 7.5 and EC of $5.2\left(\mathrm{dS} \mathrm{m}^{-1}\right)$. Zinc and manganese sulfates were applied two times at the rate of $0,0.3$ and 0.6 percent under a factorial design on the base of completely randomized blocks. Mn sprays had positive significant effects on the fruit yield, the aril/peel ratio, TSS, weight of 100 arils, juice content of arils, anthocyanin index, fruit diameter and leaf area. Zn effects were also significant for TSS, TSS/TA ratio, juice content of arils and leaf area. Foliar spray of Mn significantly increased $\mathrm{Mn}$ and $\mathrm{N}$ but decreased $\mathrm{Zn}$ and $\mathrm{Cu}$ concentrations in leaves. Foliar sprays of $\mathrm{Zn}$ significantly increased $\mathrm{Zn}$ but decreased $\mathrm{Mn}$ and $P$ concentrations in the leaves. According to the results, the suitable combination of these two micronutrients for studied characters of pomegranate under prevailing conditions was foliar spray of $0.6 \% \mathrm{MnSO}_{4}$ and $0.3 \% \mathrm{ZnSO}_{4}$.
\end{abstract}

Keywords: Punica granatum, yield, arils, mineral elements, micronutrients. 


\section{Introduction}

Pomegranate (Punica granatum L.) belonging to the Punicaceae family, is one of the favorite table fruits grown in tropical and sub-tropical regions. This plant is native of Iran and is extensively cultivated in the Mediterranean region since ages (Sheikh and Manjula, 2009). The edible part of the fruit is the seeds having a fleshy covering and called arils, which are eaten fresh or used for making juice, jam and paste. In addition, the fruit is also valued for its pharmaceutical properties. The fruit peel, and the tree stem and root bark and leaves are good source of secondary metabolites such as tannins, dyes and alkaloids (Mirdehghan and Rahemi, 2007). The incidence of micronutrient deficiencies in fruit crops has increased markedly in recent years due to intensive cropping, losses of micronutrients through leaching, decreased proportions of farm manure application compared to chemical fertilizers, increased purity of chemical fertilizers, soil erosion and use of marginal lands (with high $\mathrm{pH}$ and EC) for crop production (Zia et al., 2006). The climate change by weather warming and drying might be another important reason for the disorders.

Zinc ( $\mathrm{Zn})$ is an essential trace element for plants, being involved in many enzymatic reactions and is necessary for their good growth and development. Zinc is also involved in regulating the protein and carbohydrate metabolism (Swietlik, 1999). Zinc availability to plants is reduced in high $\mathrm{pH}$ soils. Two main theories are offered to account for high $\mathrm{Zn}$ deficiency incidence on calcareous soils. First, the solubility of $\mathrm{Zn}$ in these soils to be decreased up to 100 fold per unit increase in $\mathrm{pH}$, and the second theory which is based on the adsorption of this element by calcium carbonate $\left(\mathrm{CaCO}_{3}\right)$; the carbonate found in such soils forms an insoluble complex with $\mathrm{Zn}$ added as zinc sulfate (Rasouli-Sadeghiani et al., 2002). Zinc deficiency is commonly observed in pomegranate orchards of Iran (Taghavi, 2000; Daryashenas and Dehghani, 2006). Zinc uptake rate was faster in mango trees when zinc sulfate was foliar applied as compared with its soil application (Bahadur et al., 1998). However, the foliar or soil application of zinc sulfate showed no effect on fruit yield and quality of mango, except for TSS in the fruit.

Similar to zinc, manganese also is a heavy metal micronutrient, the functions of which are fairly known. It is involved in the oxygen-evolving step of photosynthesis and membrane function, as well as serving as an important activator of numerous enzymes in the cell (Wiedenhoeft, 2006). Soil application of Mn is problematic, since its efficiency depends on many soil factors, including soil $\mathrm{pH}$. A suitable method for the correction and /or prevention of Mn deficiency in plants is the foliar application of ionic or chelated solution forms of this nutrient (Papadakis et al., 2007). Silva et al. (2009) reported that the application of lime for orange trees for correction of soil $\mathrm{pH}$ resulted to reduced manganese concentrations in leaves proportional to increased lime in the soil. In addition, correlation between the time pass after liming with leaf manganese levels was found. Two chemical forms are mostly used for the correction of Mn deficiency of fruit trees, the inorganic $\left(\mathrm{MnSO}_{4}\right)$ and organic (Mn EDTA) forms (Papadakis et al., 2005). According to results of some experiments on apple trees (Thalheimer and Paoli, 2002) and orange trees (Papadakis et al., 2005), foliar application of manganese sulfate was more effective than manganese chelate in increasing leaf Mn concentrations. Broschat (1991) also stated that with foliar application of four soluble Mn sources, only manganese sulfate consistently increased Mn concentrations in the pygmy date palm leaves. 
The literature on $\mathrm{Zn}$ and $\mathrm{Mn}$ fertilization of pomegranate is scarce. Balakrishnan et al. (1996) reported that foliar application of $0.25 \%$ each of zinc sulfate, manganese sulfate and iron sulfate combined with $0.15 \%$ boric acid, significantly increased fruit yield and juice content of pomegranate fruit. In addition, foliar application of $\mathrm{Zn}$ and $\mathrm{Mn}$ alone or in combination with each other showed significant increase in fruit yield of sweet oranges (Tariq et al., 2007).

The aim of this study was to assess the effect of foliar spray of zinc and manganese sulfates on some pomegranate fruit traits including yield and number of fruits per tree, average fruit weight, the aril/peel ratio, weight of 100 arils, fruit length and diameter, TSS, TA, TSS/TA ratio, juice content of arils, anthocyanin index and peel thickness. Also, the effects of these elements on concentration of some other nutrients in the leaves were assessed.

\section{Materials and Methods}

The experiment was conducted during 2010 in a commercial orchard (Kesht \& Sanate Khooshehay e Zarin e Saveh) located at Saveh in Markazi Province of Iran. The area is semiarid, with an average annual rainfall of about $200 \mathrm{~mm}$, which is mostly precipitated in the winter, and average annual temperature is $18{ }^{\circ} \mathrm{C}$ and is one of the major pomegranate production centers in Iran. Seventy-two pomegranate (Punica granatum cv. Malas e Torsh e Saveh) six years old trees that their 3 years old aerial parts had been developed after the severe winter injury of 2006 and spaced at $2.5 \times 4 \mathrm{~m}$, were selected for experiment. All trees had uniform vigor and were trained to single trunk, as well as being under a drip irrigation system. The orchard was receiving the current applications for nutrition and other horticultural practices. The physical and chemical properties of the soil for the orchard are presented in Table 1.
Table 1. Physical and chemical properties of the orchard soil used in the study (compound soil samples from depths of 0-30 and 31- $60 \mathrm{~cm}$ )

\begin{tabular}{ll}
\hline Texture & SL \\
Saturation Percent (\%) & 26 \\
$\mathrm{EC}\left(\mathrm{dSm}^{-1}\right)$ & 5.2 \\
$\mathrm{pH}$ & 7.5 \\
Total Neutralizing Value (T.N.V \%) & 28 \\
Organic Carbon (\%) & 0.19 \\
Total nitrogen (\%) & 0.023 \\
$\mathrm{P}\left(\mathrm{mg} \mathrm{kg}^{-1}\right)$ & 4.5 \\
$\mathrm{~K}\left(\mathrm{mg} \mathrm{kg}^{-1}\right)$ & 195 \\
$\mathrm{Fe}\left(\mathrm{mg} \mathrm{kg}^{-1}\right)$ & 4 \\
$\mathrm{Zn}\left(\mathrm{mg} \mathrm{kg}^{-1}\right)$ & 0.7 \\
$\mathrm{Cu}\left(\mathrm{mg} \mathrm{kg}^{-1}\right)$ & 0.3 \\
$\mathrm{Mn}\left(\mathrm{mg} \mathrm{kg}^{-1}\right)$ & 7 \\
\hline
\end{tabular}

The experiment was laid out as a factorial design on the base of completely randomized blocks with four replications and two trees per replication. Aqueous solution of $\mathrm{MnSO}_{4} \cdot \mathrm{H}_{2} \mathrm{O}$ (Merck) and $\mathrm{ZnSO}_{4} \cdot 7 \mathrm{H}_{2} \mathrm{O}$ (Merck) were applied at the rate of $0,0.3$ and 0.6 percent. The treatments were applied two times on the trees, first, at 15 days before full bloom and the second, one month after the first application. Sprays were applied in the morning (6-9 a.m.) using a hand pressure sprayer. At harvest, the fruits were weighed and counted separately for each tree, and then the yield $\left(\mathrm{Kg} \mathrm{tree}{ }^{-1}\right)$ was calculated in each treatment. Average fruit weight was expressed as a fraction of the fruit yield to number of fruit/tree. Four sound fruits per each replicate were selected in 12 October to calculate the other studied characters. Fruit length and diameter measured with digital caliper and averaged for each replicate. To measure the aril/ peel ratio, after removing the arils from the fruit peel and placental parts by hand, separated arils and 
the remaining parts of fruit were weighed, then this character was expressed as a fraction of the total aril weight to total peel weight in each fruit. Total Soluble Solids (TSS) was measured using a hand-held refractometer. Titrable acidity (TA) was determined by titration with an aliquot of juice against $0.1 \mathrm{~N}$ $\mathrm{NaOH}$ and was expressed as citric acid percentage (Al-Maiman and Ahmad, 2002). Juice content of arils measured for $100 \mathrm{~g}$ of arils by extracting the juice by hand and expressed as percentage. To determine anthocyanin content, first, the juice sample was centrifuged (4 minutes at $9500 \mathrm{rpm}$ ), then was diluted with distilled water (the ratio of 1 juice to 3 water) and then the absorption by spectrophotometer at 510 $\mathrm{nm}$ wavelenght was read and recorded and showed as anthocyanin index (Sarkhosh et al., 2009). Peel thickness was measured with digital caliper at the thinnest parts.

In order to determine the leaf nutrients concentration, about 30 leaves were collected from each tree in early August from non-fruiting, spring growth shoots, so that two to three fully expanded mature leaves were collected from the middle of shoots. Leaf samples were washed first with tap water, and next with distilled water and non-ionic detergent. Then they were dried with an air oven at $70^{\circ} \mathrm{C}$ and subsequently ground manually with mortar and pestle. One gram of powder was burned in muffle oven at $550 \pm 25^{\circ} \mathrm{C}$. The resulting white ash was then dissolved in $10 \mathrm{ml}$ of $2 \mathrm{~N} \mathrm{HCl}$ and adjusted to a volume of $100 \mathrm{ml}$ by distilled water for determination of macro- and micronutrients (Chapman and Pratt, 1961). Zn, Mn, Fe and $\mathrm{Cu}$ contents were measured using an atomic absorp- tion spectrophotometer. Potassium was determined by flame photometer and phosphorous content analyzed by the molybdovanadate yellow color method by spectrophotometer. Total nitrogen content was determined using Kjeldhal method. Data were analyzed of variance (ANOVA) and differences among the means were determined for significance using Duncan Multiple Range Test at the 5\% level using the SAS software version 9.1.

\section{Results and Discussion}

\subsection{Fruit yield, number of fruit/tree and average fruit weight}

Results showed that Mn sprays at both levels significantly increased fruit yield but $\mathrm{Zn}$ sprays had no significant effect on this character. The maximum fruit yield of $8.1 \mathrm{~kg}$ tree ${ }^{-1}$ was obtained from trees receiving $0.6 \% \mathrm{MnSO}_{4}+0.3 \% \mathrm{ZnSO}_{4}$ (Table 2). Similar results had been reported that foliar spray of $\mathrm{Mn}$ increased fruit yield in 'Ganesh' pomegranate (Bambal et al., 1991) and 'Valencia' orange (Labanauskas et al., 1963). Mn sprays increased number of fruit/tree and fruit average weight, although the increase was not statistically significant, therefore the increase in fruit yield caused by Mn could be due to the increase in number of fruit/tree as well as fruit average weight. $\mathrm{Zn}$ application had no effect on these traits. Similar results also showed that $\mathrm{Zn}$ sprays had no effect on fruit yield in pomegranate (El-Khawaga, 2007; Khorsandi et al., 2009) and 'Valencia' oranges (Labanauskas and Puffer, 1964). 
Table 2. Effect of foliar spray of zinc and manganese sulfates on fruit yield $\left(\mathrm{kg} \mathrm{tree}^{-1}\right)$, number of fruit $/$ tree $\left(\mathrm{N}^{\circ}\right.$ of Fruit/tree), fruit average weight (Fruit Av. Wt.), the aril/peel ratio, TSS, TA and TSS/TA ratio of pomegranate fruits.

\begin{tabular}{|c|c|c|c|c|c|c|c|c|}
\hline \multicolumn{2}{|c|}{ Treatment } & \multirow{2}{*}{$\begin{array}{c}\text { Fruit } \\
\text { Yield } \\
\left(\mathrm{kg} \mathrm{tree}^{-1}\right)\end{array}$} & \multirow{2}{*}{$\begin{array}{c}\text { No. of } \\
\text { Fruit/ } \\
\text { Tree }\end{array}$} & \multirow{2}{*}{$\begin{array}{l}\text { Fruit Av. Wt } \\
\qquad(\mathrm{g})^{2}\end{array}$} & \multirow{2}{*}{$\begin{array}{l}\text { The aril/ } \\
\text { peel ratio }\end{array}$} & \multirow{2}{*}{$\begin{array}{c}\text { TSS } \\
\left({ }^{\circ} \text { Brix }\right)\end{array}$} & \multirow{2}{*}{$\begin{array}{c}\text { TA } \\
(\%)\end{array}$} & \multirow{2}{*}{$\begin{array}{c}\text { TSS/TA } \\
\text { ratio }\end{array}$} \\
\hline $\begin{array}{c}\mathrm{MnSO}_{4} \\
(\%)\end{array}$ & $\begin{array}{c}\mathrm{ZnSO}_{4} \\
(\%)\end{array}$ & & & & & & & \\
\hline 0 & 0 & $6.7 \mathrm{c}$ & $28.37 \mathrm{a}$ & $240.7 \mathrm{a}$ & $1.68 \mathrm{c}$ & $14.28 \mathrm{c}$ & $1.78 \mathrm{a}$ & $8.00 \mathrm{~b}$ \\
\hline 0 & 0.3 & 7.0abc & $28.87 \mathrm{a}$ & $246.9 \mathrm{a}$ & $1.73 b c$ & $15.20 \mathrm{~b}$ & $1.78 \mathrm{a}$ & $8.54 a$ \\
\hline 0 & 0.6 & $6.8 \mathrm{bc}$ & $28.25 \mathrm{a}$ & $243.5 \mathrm{a}$ & $1.69 \mathrm{bc}$ & $15.00 \mathrm{~b}$ & $1.77 \mathrm{a}$ & $8.46 \mathrm{a}$ \\
\hline 0.3 & 0 & $7.3 \mathrm{abc}$ & $29.50 \mathrm{a}$ & $250.8 \mathrm{a}$ & $1.79 \mathrm{abc}$ & $14.96 \mathrm{~b}$ & $1.81 \mathrm{a}$ & $8.27 \mathrm{ab}$ \\
\hline 0.3 & 0.3 & $7.7 \mathrm{abc}$ & $30.87 \mathrm{a}$ & $255.7 \mathrm{a}$ & $1.79 \mathrm{abc}$ & $15.38 \mathrm{ab}$ & $1.80 \mathrm{a}$ & $8.54 \mathrm{a}$ \\
\hline 0.3 & 0.6 & 7.2abc & $29.25 \mathrm{a}$ & $246.7 \mathrm{a}$ & $1.74 \mathrm{abc}$ & $15.13 b$ & $1.78 \mathrm{a}$ & $8.49 \mathrm{a}$ \\
\hline 0.6 & 0 & $7.8 \mathrm{abc}$ & $30.87 \mathrm{a}$ & $260.6 \mathrm{a}$ & $1.88 \mathrm{a}$ & $15.11 \mathrm{~b}$ & $1.83 \mathrm{a}$ & $8.20 \mathrm{ab}$ \\
\hline 0.6 & 0.3 & $8.1 \mathrm{a}$ & $31.12 \mathrm{a}$ & $261.8 \mathrm{a}$ & $1.84 \mathrm{ab}$ & $15.73 \mathrm{a}$ & $1.82 \mathrm{a}$ & $8.60 \mathrm{a}$ \\
\hline 0.6 & 0.6 & 7.9ab & $30.37 \mathrm{a}$ & $259.9 \mathrm{a}$ & $1.79 \mathrm{abc}$ & $15.22 b$ & $1.80 \mathrm{a}$ & $8.46 \mathrm{a}$ \\
\hline \multicolumn{9}{|c|}{ Significance } \\
\hline \multicolumn{2}{|c|}{$\mathrm{Mn}$} & $* *$ & NS & NS & $* *$ & $* *$ & NS & NS \\
\hline \multicolumn{2}{|c|}{$\mathrm{Zn}$} & NS & NS & NS & NS & $* *$ & NS & $* *$ \\
\hline \multicolumn{2}{|c|}{$\mathrm{Mn} \times \mathrm{Zn}$} & NS & NS & NS & NS & NS & NS & NS \\
\hline
\end{tabular}

Mean separation within columns by Duncan Multiple Range Test at $p \leq 0.05$

$\mathrm{NS}, * * *$. Insignificant or significant at $p \leq 0.05$ or 0.01 , respectively

3.2 The aril/peel ratio, peel thickness and weight of 100 arils

With application of manganese, the aril/peel ratio followed an increasing trend and foliar spray of $0.6 \%$ $\mathrm{MnSO}_{4}$ significantly increased this character. Peel thickness showed decreasing trend with foliar spray of manganese sulfate but was not statistically significant. In addition, decrease of the aril/peel ratio was observed by zinc application compared to manganese spray in this experiment (Table 2). Similar results exist, associated with increasing in fruit peel weight and reducing fruit arils in 'Manfaluty' pomegranate as affected by Zn spray (El-Khawaga, 2007). Manganese had significant positive effect on weight of 100 arils but zinc had no significant effect on it. Among the applied treatments, $0.6 \% \mathrm{MnSO}_{4}$ alone and in combination with both levels of $\mathrm{ZnSO}_{4}$ (0.3 and 0.6 percent) and also combination of $0.3 \% \mathrm{MnSO}_{4}$ and $0.3 \% \mathrm{ZnSO}_{4}$ significantly increased weight of 100 arils (Table 3 ). 
Table 3. Effect of foliar spray of zinc and manganese sulfates on weight of 100 arils, juice content of arils, anthocyanin index, peel thickness, fruit length, fruit diameter and leaf area of pomegranate.

\begin{tabular}{|c|c|c|c|c|c|c|c|c|}
\hline \multicolumn{2}{|c|}{ Treatment } & \multirow{2}{*}{$\begin{array}{c}\text { Weight } \\
\text { of } 100 \\
\text { arils (g) }\end{array}$} & \multirow{2}{*}{$\begin{array}{c}\text { Juice } \\
\text { content } \\
(\%)\end{array}$} & \multirow[b]{2}{*}{$\mathbf{A n}^{1}$} & \multirow{2}{*}{$\begin{array}{c}\text { Peel } \\
\text { thickness } \\
(\mathrm{mm})\end{array}$} & \multirow{2}{*}{$\begin{array}{c}\text { Fruit } \\
\text { length } \\
(\mathrm{cm})\end{array}$} & \multirow{2}{*}{$\begin{array}{c}\text { Fruit } \\
\text { diameter } \\
(\mathrm{cm})\end{array}$} & \multirow{2}{*}{$\begin{array}{l}\text { Leaf area } \\
\quad\left(\mathbf{m m}^{2}\right)\end{array}$} \\
\hline $\begin{array}{c}\mathrm{MnSO}_{4} \\
(\%)\end{array}$ & $\begin{array}{c}\mathrm{ZnSO}_{4} \\
(\%)\end{array}$ & & & & & & & \\
\hline 0 & 0 & $31.2 \mathrm{~b}$ & $65.6 \mathrm{c}$ & $0.254 \mathrm{~b}$ & $2.12 \mathrm{a}$ & $7.37 \mathrm{a}$ & $7.57 \mathrm{~b}$ & $470.7 \mathrm{c}$ \\
\hline 0 & 0.3 & $32.3 \mathrm{ab}$ & $67.1 \mathrm{abc}$ & $0.273 \mathrm{ab}$ & $2.08 \mathrm{a}$ & $7.72 \mathrm{a}$ & 7.91ab & $585.2 \mathrm{ab}$ \\
\hline 0 & 0.6 & $32.0 \mathrm{ab}$ & $66.0 \mathrm{bc}$ & $0.261 b$ & $2.12 \mathrm{a}$ & $7.59 a$ & $7.87 \mathrm{ab}$ & $497.5 \mathrm{~cd}$ \\
\hline 0.3 & 0 & $32.6 \mathrm{ab}$ & $67.6 \mathrm{ab}$ & $0.290 \mathrm{ab}$ & $1.98 \mathrm{a}$ & $7.61 \mathrm{a}$ & $7.96 \mathrm{ab}$ & $492.0 \mathrm{c}$ \\
\hline 0.3 & 0.3 & $33.1 \mathrm{a}$ & $67.9 \mathrm{ab}$ & $0.298 \mathrm{ab}$ & $2.07 \mathrm{a}$ & $7.71 \mathrm{a}$ & $8.14 \mathrm{ab}$ & $614.2 \mathrm{a}$ \\
\hline 0.3 & 0.6 & $32.8 \mathrm{ab}$ & $66.5 \mathrm{abc}$ & $0.265 \mathrm{ab}$ & $2.13 \mathrm{a}$ & $7.63 a$ & $7.87 \mathrm{ab}$ & $592.4 \mathrm{a}$ \\
\hline 0.6 & 0 & $33.1 \mathrm{a}$ & $68.1 \mathrm{a}$ & $0.303 \mathrm{ab}$ & $1.89 \mathrm{a}$ & $7.73 \mathrm{a}$ & $8.15 \mathrm{ab}$ & $584.4 \mathrm{ab}$ \\
\hline 0.6 & 0.3 & $33.5 \mathrm{a}$ & $68.2 \mathrm{a}$ & $0.328 \mathrm{a}$ & $2.00 \mathrm{a}$ & $7.82 \mathrm{a}$ & $8.20 \mathrm{a}$ & $586.3 \mathrm{ab}$ \\
\hline 0.6 & 0.6 & $33.0 \mathrm{a}$ & $67.1 \mathrm{abc}$ & $0.287 \mathrm{ab}$ & $2.11 \mathrm{a}$ & $7.74 a$ & $8.10 \mathrm{ab}$ & $615.6 \mathrm{a}$ \\
\hline \multicolumn{9}{|c|}{ Significance } \\
\hline \multicolumn{2}{|c|}{$\mathrm{Mn}$} & $* *$ & $* *$ & $*$ & NS & NS & $*$ & $*$ \\
\hline \multicolumn{2}{|c|}{$\mathrm{Zn}$} & NS & $*$ & NS & NS & NS & NS & $* *$ \\
\hline \multicolumn{2}{|c|}{$\mathrm{Mn} \times \mathrm{Zn}$} & NS & NS & NS & NS & NS & NS & NS \\
\hline
\end{tabular}

Mean separation within columns by Duncan Multiple Range Test at $p \leq 0.05$ $\mathrm{NS}, * * *$, Insignificant or significant at $p \leq 0.05$ or 0.01 , respectively

${ }^{1}$ Anthocyanin index: Absorption at $510 \mathrm{~nm}$ for 1:3 diluted juice

\subsection{Fruit diameter, fruit length and leaf area}

Mn application increased fruit diameter and fruit length but only the $0.6 \%$ rate of manganese was significant on fruit diameter. $\mathrm{Zn}$ sprays had no significant effect on fruit length and diameter. There was significant effect of zinc and manganese sprays on leaf area, so that treated trees by combination of $\mathrm{Zn}$ and $\mathrm{Mn}$ had greater leaf area (Table 3), which is in agreement with data concerning other fruits to foliar spray of $\mathrm{Zn}$ (Rasouli-Sadeghiani et al., 2002; Arora and Singh, 1970).
3.4 Juice content of arils, anthocyanin index, TSS, TA and TSS/TA ratio

Mn spray had significant effect on juice content of arils and anthocyanin index. Foliar sprays of $\mathrm{Mn}$ at both levels ( 0.3 and 0.6 percent) significantly increased juice content of arils and the $0.6 \%$ application of manganese had also significant increase on anthocyanin index. Zn spray had no significant effect on anthocyanin index. The $0.3 \%$ application of $\mathrm{ZnSO}_{4}$ significantly increased juice content of arils, while the rate 
of $0.6 \% \mathrm{ZnSO}_{4}$ had negative impact on juice content of arils and anthocyanin index. Combination of manganese sulfate at $0.6 \%$ and zinc sulfate at $0.3 \%$ was the best treatment on increasing juice content of arils and anthocyanin index (Table 3). By foliar application of zinc, decrease in percentage of juice in 'Valencia' orange fruit had been already reported (Labanauskas et al., 1963). El-Khawaga (2007) stated that decreasing in juice percent of pomegranate fruits caused by $\mathrm{Zn}$ spray was related to producing smaller fruits, increasing in fruit peel weight and reducing total arils of fruits.

In our experiment each of $\mathrm{Mn}$ and $\mathrm{Zn}$ sprays had significant positive effects on TSS, and the effect of $\mathrm{ZnSO}_{4}$ was more reasonable than $\mathrm{MnSO}_{4}$ in increasing TSS, but their combination resulted in relatively higher TSS (Table 2). It has been reported that the highest TSS was obtained by foliar application of zinc sulfate $(0.4 \%)$ combined with boric acid $(0.2 \%)$ in 'Ganesh' pomegranate (Balakrishnan et al., 1996). Titrable acidity increased with application of Mn; however, $\mathrm{Zn}$ sprays decreased TA, although they were not significant (Table 2). On the contrary, it has been reported that the foliar application of zinc sulfate (2000 to $4000 \mathrm{ppm}$ ) increased titrable acidity of 'Manfaluty' pomegranate fruit (El-Khawaga, 2007). The variation in the results may be attributed to time of application of $\mathrm{Zn}$ and variable responses of different cultivars of pomegranate to zinc application or the environment conditions. Effects of $\mathrm{ZnSO}_{4}$ at both levels ( 0.3 and $0.6 \%$ ) were significant for TSS/TA ratio but $\mathrm{MnSO}_{4}$ had no significant effect on this character. Maximum juice content of arils and anthocyanin index, TSS and TSS/TA ratio were obtained from the treatment receiving $0.6 \% \mathrm{MnSO}_{4}+0.3 \% \mathrm{ZnSO}_{4}$ (Tables 2 and 3 ).

\subsection{Macro- and micronutrients in pomegranate leaves}

According to Table 4, the effects of all foliar treatments on the concentration of $\mathrm{P}, \mathrm{K}, \mathrm{Fe}$ and $\mathrm{Cu}$ were statistically insignificant. Results showed that the foliar spray of zinc and manganese sulfates significantly increased the $\mathrm{Zn}$ and $\mathrm{Mn}$ concentrations in pomegranate leaves, respectively. The highest $\mathrm{Zn}$ and Mn concentrations (139.5 $\mathrm{mg} \mathrm{kg}^{-1}$ and $163 \mathrm{mg} \mathrm{kg}^{-1}$ dry weight of leaf, respectively) obtained each in the $0.6 \%$ treatment which the $\mathrm{Zn}$ and $\mathrm{Mn}$ were applied alone (Table 4). Khorsandi et al. (2009) reported similar increase in the $\mathrm{Zn}$ concentration of pomegranate leaves. Results also showed that the applied Mn insignificantly decreased the concentrations of $\mathrm{Zn}$ and $\mathrm{Cu}$ and significantly increased concentration of $\mathrm{N}$ in pomegranate leaves. In other plants, it has been stated that $\mathrm{Mn}$ could be antagonistic on concentration of $\mathrm{Zn}$ (Tariq et al., 2007) and $\mathrm{Cu}$ (Labanauskas et al., 1963). According to the results, foliar-applied $\mathrm{Zn}$ decreased the concentration of both $\mathrm{Mn}$ and $\mathrm{P}$ and increased concentration of $\mathrm{Cu}$ in pomegranate leaves. Therefore, it can be stated that there was an antagonistic effect between $\mathrm{Zn}$ and these nutrients (Mn and P) and a synergism relation between $\mathrm{Zn}$ and $\mathrm{Cu}$. Similarly, reports are available that with $\mathrm{Zn}$ foliar sprays, the concentration of Mn decreased in orange leaves (Labanauskas and Puffer, 1964; Tariq et al., 2007) and maize leaves (Aref, 2011). According to a previous report, the concentration of $\mathrm{P}$ was low in the samples from $\mathrm{Zn}$ sprays in apple leaves (Rasouli-Sadeghiani et al., 2002). In addition, Aref (2011) stated that foliar sprays of $\mathrm{Zn}$ increased concentration of $\mathrm{Cu}$ in maize leaves. Fruit size (both length and diameter) increased with in- 
creasing the concentration of $\mathrm{MnSO}_{4}$ and the increase in fruit size was associated with $\mathrm{Mn}, \mathrm{N}$ and $\mathrm{K}$ concentrations in pomegranate leaves (Table 4). Fallahi et al. (1997) stated that levels of leaf $\mathrm{N}$ had positive effect on fruit size in apple, so that heavier fruits ob- tained from trees that had high levels of $\mathrm{N}$ in leaves. It should be mentioned that in present experiment, foliar spray of $0.6 \% \mathrm{ZnSO}_{4}$ in each of two times, alone and combined with both levels of $\mathrm{MnSO}_{4}$, caused necrotic spots on leaves.

Table 4. Effect of foliar spray of zinc and manganese sulfates on macro- and micronutrients concentrations (percent or $\mathrm{mgkg}^{-1}$ dry weight) in pomegranate leaves.

\begin{tabular}{|c|c|c|c|c|c|c|c|c|}
\hline \multicolumn{2}{|c|}{ Treatment } & \multirow{2}{*}{$\begin{array}{l}N \\
(\%)\end{array}$} & \multirow{2}{*}{$\begin{array}{l}P \\
(\%)\end{array}$} & \multirow{2}{*}{$\begin{array}{l}K \\
(\%)\end{array}$} & \multirow{2}{*}{$\begin{array}{l}\mathrm{Fe} \\
\left(\mathrm{mg} \mathrm{kg}^{-1}\right)\end{array}$} & \multirow{2}{*}{$\begin{array}{l}\mathrm{Zn} \\
\left(\mathrm{mg} \mathrm{kg}^{-1}\right)\end{array}$} & \multirow{2}{*}{$\begin{array}{l}\text { Mn } \\
\left(\mathrm{mg} \mathrm{kg}^{-1}\right)\end{array}$} & \multirow{2}{*}{$\begin{array}{l}\mathrm{Cu} \\
\left(\mathrm{mg} \mathrm{kg}^{-1}\right)\end{array}$} \\
\hline $\begin{array}{l}\mathrm{MnSO}_{4} \\
(\%)\end{array}$ & $\begin{array}{l}\mathrm{ZnSO}_{4} \\
(\%)\end{array}$ & & & & & & & \\
\hline 0 & 0 & $1.94 \mathrm{ab}$ & $0.199 \mathrm{a}$ & $0.85 \mathrm{a}$ & $129.5 \mathrm{a}$ & $37.40 \mathrm{~b}$ & $92.20 \mathrm{~b}$ & $6.50 \mathrm{a}$ \\
\hline 0 & 0.3 & $1.81 \mathrm{~b}$ & $0.190 \mathrm{a}$ & $0.90 \mathrm{a}$ & $110.5 \mathrm{a}$ & $93.50 \mathrm{ab}$ & $86.50 \mathrm{~b}$ & $8.30 \mathrm{a}$ \\
\hline 0 & 0.6 & $1.81 \mathrm{~b}$ & $0.182 \mathrm{a}$ & $0.86 \mathrm{a}$ & $126.5 \mathrm{a}$ & $139.5 \mathrm{a}$ & $74.50 \mathrm{~b}$ & $8.35 \mathrm{a}$ \\
\hline 0.3 & 0 & $1.92 \mathrm{ab}$ & $0.260 \mathrm{a}$ & $0.99 \mathrm{a}$ & $136.5 \mathrm{a}$ & $38.40 \mathrm{~b}$ & $162.5 \mathrm{a}$ & $5.15 \mathrm{a}$ \\
\hline 0.3 & 0.3 & $2.09 \mathrm{a}$ & $0.230 \mathrm{a}$ & $1.00 \mathrm{a}$ & $91.00 \mathrm{a}$ & $64.50 \mathrm{ab}$ & $89.80 \mathrm{~b}$ & $5.15 \mathrm{a}$ \\
\hline 0.3 & 0.6 & $2.03 \mathrm{ab}$ & $0.228 \mathrm{a}$ & $0.98 \mathrm{a}$ & $91.50 \mathrm{a}$ & $74.20 \mathrm{ab}$ & $89.70 \mathrm{~b}$ & $6.85 \mathrm{a}$ \\
\hline 0.6 & 0 & $1.97 \mathrm{ab}$ & $0.224 \mathrm{a}$ & $0.93 \mathrm{a}$ & $112.5 \mathrm{a}$ & $26.50 \mathrm{~b}$ & $163.0 \mathrm{a}$ & $5.10 \mathrm{a}$ \\
\hline 0.6 & 0.3 & $2.04 \mathrm{ab}$ & $0.192 \mathrm{a}$ & $1.04 \mathrm{a}$ & $122.5 \mathrm{a}$ & $103.8 \mathrm{ab}$ & $154.0 \mathrm{a}$ & $5.35 \mathrm{a}$ \\
\hline 0.6 & 0.6 & $2.12 \mathrm{a}$ & $0.186 \mathrm{a}$ & $1.00 \mathrm{a}$ & $96.50 \mathrm{a}$ & $92.20 \mathrm{ab}$ & $122.0 \mathrm{ab}$ & $5.20 \mathrm{a}$ \\
\hline \multicolumn{9}{|c|}{ Significance } \\
\hline $\mathrm{Mn}$ & & $*$ & NS & NS & NS & NS & $* *$ & NS \\
\hline $\mathrm{Zn}$ & & NS & NS & NS & NS & $*$ & $*$ & NS \\
\hline $\mathrm{Mn} \times \mathrm{Zn}$ & & NS & NS & NS & NS & NS & NS & NS \\
\hline
\end{tabular}

Mean separation within columns by Duncan Multiple Range Test at $p \leq 0.05$

$\mathrm{NS}, * * *$, Insignificant or significant at $p \leq 0.05$ or 0.01 , respectively

According to soil and nutritional conditions of pomegranate trees cv. Malas e Torsh e Saveh, we can say that $\mathrm{Mn}$ is an important element in enhancing yield and improving the qualitative properties of this fruit. On the other hand, under conditions of present experiment, $\mathrm{Zn}$ had no significant effect on most measured characters and we can state that this nutrient element was not a limiting factor for reproductive processes of this fruit. 


\section{Conclusion}

Manganese and zinc sulfates each had significant effects on some measured characters on pomegranate, but their interaction was not significant. Application of $\mathrm{Mn}$ at both levels (0.3 and $0.6 \%$ ) increased some characters like fruit yield of trees, weight of 100 arils, fruit diameter, TSS, juice content of arils, the aril/peel ratio, anthocyanin index and leaf area. $\mathrm{Zn}$ effects were also significant for TSS, TSS/TA ratio, juice content of arils and leaf area. The treatments had no statistically significant effects on number of fruit/tree, average fruit weight, fruit length, titrable acidity and peel thickness. Foliar sprays of zinc sulfate significantly increased the $\mathrm{Zn}$ concentration but insignificantly decreased the concentrations of $\mathrm{Mn}$ and $\mathrm{P}$ in pomegranate leaves. Manganese sprays significantly increased concentration of Mn and $\mathrm{N}$ and it seems that Mn had antagonistic effects on $\mathrm{Zn}$ and $\mathrm{Cu}$ concentrations in leaves. According to presented results, the $0.6 \% \mathrm{MnSO}_{4}+$ $0.3 \% \mathrm{ZnSO}_{4}$ as foliar spray was suitable combination for the most of measured characters in pomegranate fruits and leaves during the course of this experiment.

\section{Acknowledgements}

The authors acknowledge to Mr. Mahdiyoun (Managing Director of the Kesht \& Sanate Khooshehay e Zarin e Saveh) and all employees of the orchard for cooperation during this study.

\section{References}

Al-Maiman, S.A., Ahmad, D. 2002. Changes in physical and chemical properties during pomegranate (Punica granatum L.) fruit maturation. Food Chem. 76, 437-441.
Aref, F. 2011. Influence of zinc and boron nutrition on copper, manganese and iron concentrations in maize leaf. Aust. J. Basic Appl. Sci. 5 (7), 52-62.

Arora, J.S., Singh, J.R. 1970. Some effects of foliar sprays of zinc sulphate on growth, yield and fruit quality of guava (Psidium guajava L.). J. Jpn. Soc. Hortic. Sci. 39 (3), 1-5.

Bahadur, L., Malhi, C.S., Singh, Z. 1998. Effect of foliar and soil applications of zinc sulphate on zinc uptake, tree size, yield, and fruit quality of mango. J. Plant Nutr. 21 (3), 589-600.

Balakrishnan, K., Venkatesan, K., Sambandamurti, S. 1996. Effect of foliar application of Zn, Fe, Mn and $\mathrm{B}$ on yield and quality of pomegranate $\mathrm{cv}$. Ganesh. Orissa Journal of Horticulture. 24 (1), 33-35.

Bambal, S.B., Wavhal, K.N., Nasalkar, S.D. 1991. Effect of foliar application of micro-nutrients on fruit quality and yield of pomegranate (Punica granatum L. cv. Ganesh). Maharashtra Journal of Horticulture. 5 (2), 32-36.

Broschat, T.K. 1991. Effect of manganese source on manganese uptake by pygmy date palms. HortScience. 26 (11), 1389-1391.

Chapman, H.D., Pratt, P.F. 1961. Methods of Analysis for Soils, Plants and Water. University of California, Berkelery, CA, USA, 309p.

Daryashenas, A.M., Dehghani, F. 2006. Determination of Dris reference norms for pomegranate in Yazd Province. Iranian J. Soil. Water Sci. 20, $1-10$.

El-Khawaga, A.S. 2007. Reduction in fruit cracking in 'Manfaluty' pomegranate following a foliar application with paclobutrazol and zinc sulphate. J. Appl. Sci. Res. 3 (9), 837-840. 
Fallahi, E., Colt, W.M., Seyedbagheri, M.M. 1997. Influence of foliar application of nitrogen on tree growth, precocity, fruit quality, and leaf mineral nutrients in young 'Fuji' apple trees on three rootstocks. J. Tree Fruit Production. 2 (1), 1-11.

Khorsandi, F., AlaeiYazdi, F., Vazifehshenas, M.R. 2009. Foliar zinc fertilization improves marketable fruit yield and quality attributes of pomegranate. Int. J. Agr. Biol. 11 (6), 766-770.

Labanauskas, C.K., Jones, W.W., Embrleton, T.W. 1963. Effect of foliar application of manganese, zinc, and urea on yield and fruit quality of 'Valencia' oranges, and nutrient concentrations in the leaf, peel and juice. Proc. Amer. Soc. Hort. Sci. $82,142-153$.

Labanauskas, C.K., Puffer, R.E. 1964. Effect of foliar application of manganese, zinc, and urea on 'Valencia' oranges yield and foliage composition. Proc. Amer. Soc. Hort. Sci. 84, 158-164.

Mirdehghan, S.H., Rahemi, M. 2007. Seasonal changes of mineral nutrient and phenolic in pomegranate (Punica granatum L.) fruit. Sci. Hortic. 111, 120-127.

Papadakis I.E., Sotiropoulos, T.E., Therios, I.N. 2007. Mobility of iron and manganese within two citrus genotypes after foliar application of iron sulfate and manganese sulfate. J. Plant Nutr. 30, 13851396.

Papadakis, I.E., Protopapadakis, E., Therios, I.N., Tsirakoglou, V. 2005. Foliar treatment of Mn deficient 'Washington Navel' orange trees with two Mn sources. Sci. Hortic. 106, 70-75.

Rasouli-Sadeghiani, M.H., Malakouti, M.J., Samar, S.M. 2002. The effectiveness of different application methods of zinc sulfate on nutritional conditions of apple in calcareous soil of Iran. $17^{\text {th }}$ World Congress of Soil Science, Thailand, paper no, 2151.
Sarkhosh, A., Zamani, Z., Fatahi, R., Sayyari, M 2009. Antioxidant activity, total phenols, anthocyanin, ascorbic acid content and woody portion index (wpi) in Iranian soft-seed pomegranate fruits, Food. 3 (1), 68-72.

Sheikh, M.K., Manjula, N. 2009. Effect of split application of $\mathrm{N}$ and $\mathrm{K}$ on growth and fruiting in 'Ganesh' pomegranate (Punica granatum L.). Acta Hort. 818, 213-217.

Silva, M.A.C., Natale, W., Prado, R.M., Chiba, M.K 2009. Liming and manganese foliar levels in orange. J. Plant Nutr. 32, 694-702.

Swietlik, D. 1999. Zinc nutrition in horticultural crops. Horticultural Reviews. John Wiley \& Sons, Inc. New York. 23, 109-180.

Taghavi, G.R. 2000. The effects of macronutrients and foliar application of zinc sulfate on the yield and quality of pomegranate. Proc of $2^{\text {nd }}$ National Conference on the Optimum Utilization of Chemical Fertilizer and Pesticides in Agriculture, Karaj, Iran, 230- 231.

Tariq, M., Sharif, M., Shah, Z., Khan, R. 2007. Effect of foliar application of micronutrients on the yield and quality of sweet orange (Citrus sinensis L.). Pak. J. Biol. Sci. 10 (11), 1823- 1828.

Thalheimer, M., Paoli, N. 2002. Foliar absorption of $\mathrm{Mn}$ and Mg: Effects of product formulation, period of application and mutual interaction of apple. Acta Hort. 54, 157-164.

Wiedenhoeft, A.C. 2006. Micrunutrients. In: W.G. Hapkins (ed), Plant Nutrition. Chelsea House Publications, pp: 14-36.

Zia, M.H., Ahmad, R., Khalig, I., Irshad, M. 2006. Micronutrients status and management in orchards: applied aspects. Soil \& Environ. 25, 6-16. 